\title{
Effect of Corporate Social Responsibility Disclosure, Capital Structure, and Ownership Structure on Value of The Firm with Intervening Variables of Financial Performance and Dividend Policy in Manufacturing Companies Listed in Indonesia Stock Exchange
}

\author{
S Rahayuningsih ${ }^{1}$, D R Prihastuty ${ }^{2}$, Hwihanus ${ }^{3}$ \\ \{srirahayuningsih@untag-sby.ac.id ${ }^{1}$,dyahrini@untag-sby.ac.id ${ }^{2}$, hwihanus@untag-sby.ac.id ${ }^{3}$ \} \\ ${ }^{1,2,3}$ Economics and Business Faculty, University of 17 Agustus 1945 Surabaya, Indonesia
}

\begin{abstract}
This study aims to examine and analyze the effect of CSR disclosure, capital structure, ownership structure on the value of firms with Financial Performance and Dividend Policy as an intervening variable in manufacturing companies listed on the Stock Exchange for the period 2014-2016. The sample used was 33 samples. This research uses purposive sampling technique while data analysis uses partial least square (PLS). The results showed that almost all the research hypotheses were accepted and had a significant effect with a significant level of 5\% with t-table 1,960 except the Capital Structure of Dividend Policy (H5) and Capital Structure of Value of the Firm (H6) not significant so that the hypothesis was rejected in the study. Management needs to consider the composition of the capital structure established by the company's management so that dividend policies can be applied according to the company's objectives.
\end{abstract}

Keywords: corporate social responsibility disclosure, capital structure, ownership structure, financial performance, dividend policy, company value

\section{Introduction}

Company value is the performance of the company which is reflected in the stock price formed by demand and supply in the capital market which reflects the community's assessment of company performance [1]. In general, the public and investors tend to judge the company as limited to the value of the company's shares in the capital market which experience significant changes every year. The company value for investors as material for consideration of company operational activities reflected in auditor opinion in the survival of the company [2]. Corporate value can also be seen from the company's assets in generating profits and fulfilling its obligations.

The ups and downs of stock prices in the capital market become an interesting phenomenon to discuss regarding the issue of fluctuations in the value of the company which are influenced by several factors including corporate social responsibility, ability to pay obligations, the company's Ownership Structure, financial performance of a company and ability to pay 
dividends. Corporate care in the environment and society can be realized in the form of Corporate Social Responsibility (CSR). The responsibility of the company not only increases the prosperity of shareholders who emphasize an economic approach but more importantly is maintaining a harmonious relationship with stakeholders, namely employees, creditors, investors, government, community social institutions, consumers and the surrounding environment. The CSR Disclosure emphasizes companies must develop ethical, sustainable, economic, social and environmental business practices.

CSR discourse in Indonesia began to emerge since the enactment of the Limited Liability Company Law No. 40 of 2007 (UU Perseroan Terbatas No. 40 Tahun 2007), especially article 74 which requires companies to budget funds for implementing social responsibility, especially for companies in carrying out their business activities, which are related to natural resources by requiring the company to set aside a portion of net income for the implementation of CSR. Capital structure is related to the long-term expenditure of a company measured by the comparison of long-term debt with its own capital [3]. A company will choose the optimal capital structure with low capital costs that are able to generate profits and reflect high corporate value.

The company's financial performance is one of the factors that investors see to determine stock investment. For a company, maintaining and improving Financial Performance is a necessity in order to continue to exist and remain attractive to investors. The financial statements issued by the company are a reflection of the company's Financial Performance. The financial information produced has a function as a means of information, a tool of management accountability to the owner of the company, a description of the indicators of the company's success and as a consideration in decision making. Dividend policy also plays an important role in explaining the value of the company. The conflict that arises about the issue is regarding the status of dividends, whether dividends can be considered good or bad news for investors [4].

\section{Literature Review}

\section{a. Management Accounting}

Management accounting is a process of identifying, measuring and reporting economic information to enable an assessment and a firm and clear decision for management. The main objective is to present reports as a business unit for the interests of internal parties in order to carry out the management process which includes planning, organizing, directing and controlling[5].

\section{b. The value of the company}

Company value [6] is the value needed by investors to make investment decisions as reflected in the company's market prices that occur when stocks are traded in the market [7] or precisely called closing prices [8]. Company value [6] is the value needed by investors to make investment decisions that are reflected in the company's market price.

The value of the company is proxied by Tobin's $Q$ which is a more rigorous measure of how effectively management uses economic resources in its power. Price to Book Value (PBV), this ratio is used to avoid weaknesses that are owned by book value. By some researchers, this ratio is considered able to describe the value of the company. Price Earning Ratio (PER) is a ratio that measures how much the comparison between the company's stock price and the profits obtained by shareholders. 


\section{c. Corporate Social Responsibility Disclosure}

Corporate Social Responsibility (CSR) is an organization's responsibility for the impact of its decisions and activities on society and the environment. CSR is manifested in the form of transparent and ethical behavior that is in line with sustainable development and public welfare considers stakeholder expectations, in line with established laws and international behavioral norms, and integrates with the organization as a whole.

CSR is a company concern that sets aside a portion of its profits (profit) for the benefit of sustainable human (people) and environmental (planet) development based on appropriate and professional procedures.

CSR aims to optimally provide information that is relevant to social, policy, program, performance and corporate contributions. The benefits of CSR to increase sales and market share, brand positioning, corporate image, company attractiveness in the eyes of investors and financial analysis, reduce operating costs.

\section{d. Capital Structure}

Capital structure is the percentage of the type of capital used by the company [9] which consists of debt (debt) and share capital (equity) to fund the operations of the company. The choice of using debit or equity contains risks that affect the value of the company. The capital structure of funding obligations is something that is uncertain but is a very important resource for all companies, while equity is a definite resource that is obtained from the inclusion of people who set up a company as venture capital [10].

Debt and equity are the two main groups of companies that have influence, level of risk, profit, and control of the company. Creditors have lower control and get the right to a fixed rate of return and are protected by contractual obligations in investment security, while shareholders have greater control over company decisions [11].

\section{e. Ownership Structure}

Ownership Structure is the percentage of shares in a company and reflects the distribution of power and influence among shareholders on the company's operations. Ownership structure can be explained from the agency approach and the asymmetry information approach. Agency approach, Ownership Structure is a mechanism to reduce conflicts of interest between managers and shareholders [12]. The information imbalance approach views the mechanism of ownership structure as a way to reduce information imbalances between insiders and outsiders through information disclosure in the capital market.

\section{f. Financial performance}

Financial performance is a factor that shows the effectiveness and efficiency of an organization in order to achieve its objectives. If Financial Performance has decreased it needs to be improved by measuring Financial Performance by analyzing financial statements using financial ratios and used as a basis for granting reward and punishment to managers and members of the organization. Performance measurement carried out every certain period is very useful to assess the progress that has been achieved by the company and produce information that is very useful for management decision making and able to create the value of the company itself to stakeholders. 


\section{g. Dividend Policy}

Dividend Policy (Halim, 2010: 96) is a decision whether the profits obtained by the company will be distributed to shareholders as dividends or will be held in the form of retained earnings for future investment financing.

\section{h. Research hypothesis}

The hypothesis that can be compiled in this study:

1. Corporate Social Responsibility Disclosure has a significant effect on Financial Performance.

2. Corporate Social Responsibility Disclosure has a significant effect on Dividend Policy

3. Corporate Social Responsibility Disclosure has a significant effect on the value of the firm.

4. Capital structure has a significant effect on Financial Performance.

5. Capital structure has a significant effect on Dividend Policy.

6. Capital structure has a significant effect on the value of the firm.

7. Ownership Structure has a significant effect on Financial Performance

8. Ownership Structure has a significant effect on Dividend Policy.

9. Ownership Structure has a significant effect on the value of the firm.

10. Financial Performance has a significant effect on Dividend Policy.

11. Financial Performance has a significant effect on Company Value.

12. Dividend Policy has a significant effect on the Value of the Firm.

\section{Research Methods}

\section{a. Population and Samples}

The population in this study is all manufacturing companies that have been and are still listed on the Indonesia Stock Exchange for the 2014-2016 period as many as 144 companies. The sample in this study were 33 manufacturing companies in the consumer goods industry sector that had been and are still listed on the Indonesia Stock Exchange for the 2014-2016 period that met the requirements of the sampling criteria. 
Table 1. Variables and indicators

\begin{tabular}{|c|c|c|c|c|}
\hline \multicolumn{3}{|l|}{ Variable } & Notation & Indicator \\
\hline \multirow{8}{*}{ 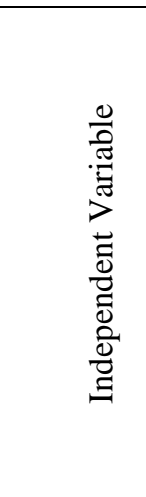 } & & \multirow{3}{*}{$\begin{array}{l}\text { Corporate Social Responsibility } \\
\left(\mathrm{X}_{1}\right)\end{array}$} & $\mathrm{X}_{1.1}$ & Economy \\
\hline & & & $\mathrm{X}_{1.2}$ & Environment \\
\hline & & & $\mathrm{X}_{1.3}$ & Social \\
\hline & & \multirow{3}{*}{ Capital Structure $\left(\mathrm{X}_{2}\right)$} & $\mathrm{X}_{2.1}$ & Debt Asset Ratio (DAR) \\
\hline & & & $\mathrm{X}_{2.2}$ & $\begin{array}{l}\text { Debt to Equity Ratio } \\
\text { (DER) }\end{array}$ \\
\hline & & & $\mathrm{X}_{2.3}$ & $\begin{array}{l}\text { Long Debt Equity Ratio } \\
\text { (LDER) }\end{array}$ \\
\hline & & \multirow{2}{*}{ Ownership Structure $\left(\mathrm{X}_{3}\right)$} & $\mathrm{X}_{3.1}$ & $\begin{array}{l}\text { Institutional Ownership } \\
\text { Structure }\end{array}$ \\
\hline & & & $\mathrm{X}_{3.2 .}$ & $\begin{array}{l}\text { Managerial Ownership } \\
\text { Structure }\end{array}$ \\
\hline \multirow{5}{*}{\multicolumn{2}{|c|}{ 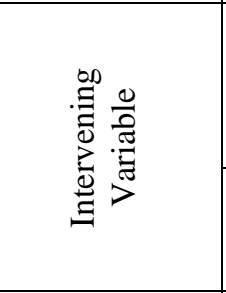 }} & \multirow{3}{*}{ Financial Performance $\left(\mathrm{Z}_{1}\right)$} & $\mathrm{Z}_{1.1}$ & Return of Assets (ROA) \\
\hline & & & $\mathrm{Z}_{1.2 .}$ & Return Of Equity (ROE) \\
\hline & & & $\mathrm{Z}_{1.3 .}$ & $\begin{array}{l}\text { Net Profit Margin } \\
\text { (NPM) }\end{array}$ \\
\hline & & \multirow[t]{2}{*}{ Dividend Policy $\left(\mathrm{Z}_{2}\right)$} & $\mathrm{Z}_{2.1}$ & $\begin{array}{l}\text { Dividend Payout Ratio } \\
(D P R)\end{array}$ \\
\hline & & & $\mathrm{Z}_{2.2}$ & Dividend Yield $(D Y)$ \\
\hline \multirow{3}{*}{ 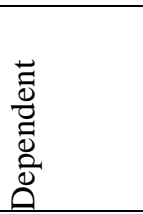 } & \multirow{3}{*}{ 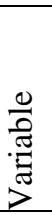 } & \multirow{3}{*}{ The value of the firm (Y) } & $\mathrm{Y}_{1.1}$ & Tobins'Q \\
\hline & & & $\mathrm{Y}_{1.2}$ & $\begin{array}{l}\text { Price To Book Value } \\
(P B V)\end{array}$ \\
\hline & & & $\mathrm{Y}_{1.3}$ & $\begin{array}{lll}\begin{array}{l}\text { Price } \\
(P E R) .\end{array} & \text { Earning } & \text { Ratio } \\
(\text { PER } & \\
\end{array}$ \\
\hline
\end{tabular}

Source: data processed

\section{b. Conceptual Framework}

The relationship between research variables can be seen in the following figure:

Figure 1. Conceptual Framework

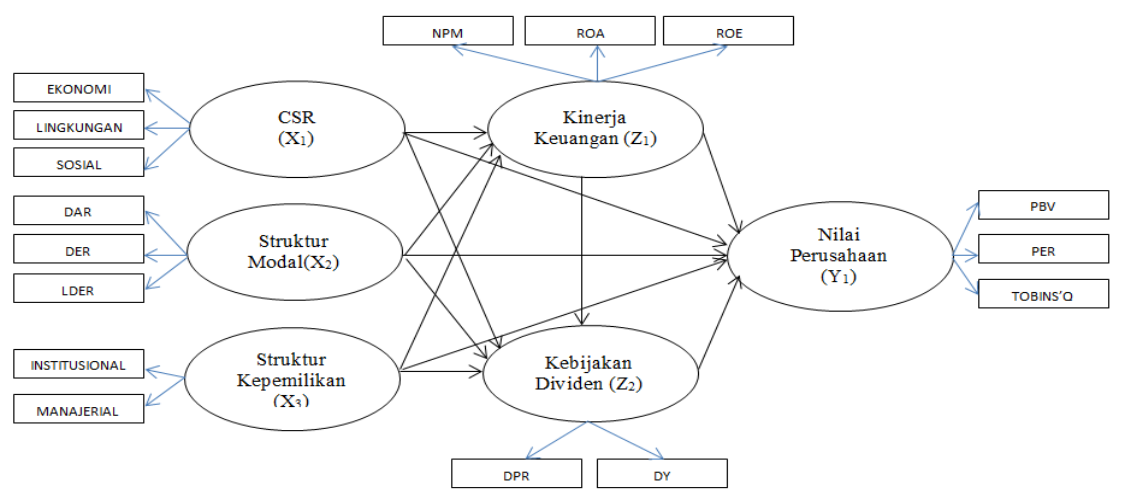




\section{c. Data analysis technique}

Data analysis in this study is descriptive analysis while statistically using Partial Least Square (PLS) applications with many indicators.

\section{Result and Discussion}

\section{a. Evaluate the Measurement (Outer), Model}

This study uses the limitation of loading factors with indicators that connect between variables with loading values above 0.5 . The test results below the loading value of 0.50 are carried out dropping and look as follows:

Figure 2. Outer Loading Model

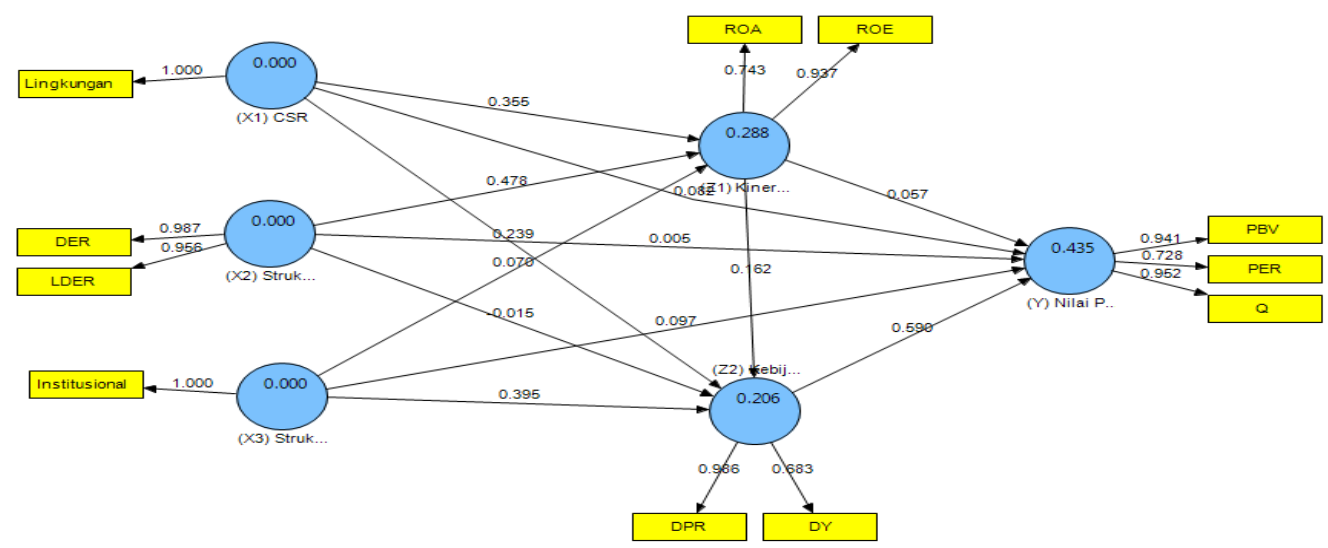

Source: data processed

\section{b. Testing of Structural Models (Inner Model)}

Structural model testing (Inner model) is used to test the relationship between latent variables and measurement results seen in R2:

1. The value of 0.288315 or $(28.8 \%)$ in the Financial Performance variable (Z1) explains the relationship between Disclosure CSR (X1), Capital Structure (X2) and Ownership Structure(X3).

2. The value of 0.205849 or $(20.6 \%)$ in the Dividend Policy variable (Z2) explains the relationship between CSR Disclosure (X1), Capital Structure (X2), Ownership Structure (X3)

3. Value of 0.434619 or $(43.4 \%)$ in variable (Y) Company Value explains the relationship between Disclosure CSR (X1), Capital Structure (X2), Ownership Structure (X3), Financial Performance (Z1) and Dividend Policy (Z2) 
Figure 3. Model Structure (Inner Model)

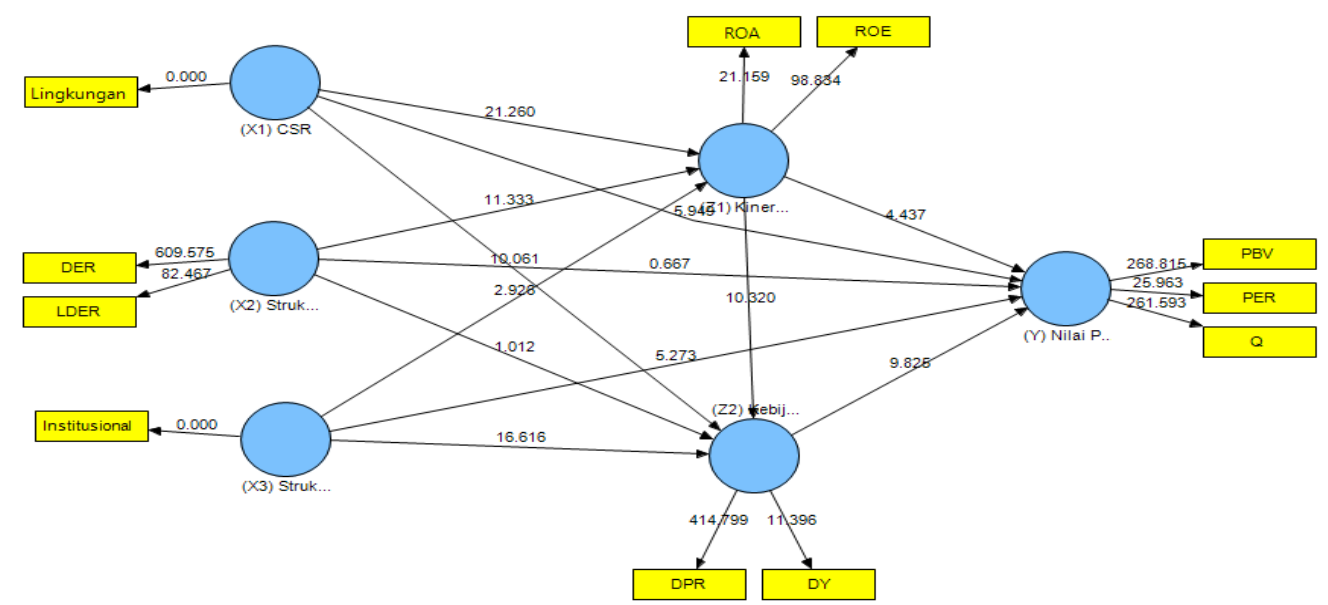

Source: data processed

Table 2. Path Coefficients (Mean, STDEV, T-Values)

\begin{tabular}{|c|c|c|c|c|c|c|c|}
\hline $\mathrm{Ha}$ & Variable & $\begin{array}{l}\text { Original } \\
\text { Sample } \\
\text { (O) }\end{array}$ & $\begin{array}{l}\text { Sample } \\
\text { Mean } \\
(\mathrm{M})\end{array}$ & $\begin{array}{l}\text { Standard } \\
\text { Deviation } \\
\text { (STDEV) }\end{array}$ & $\begin{array}{l}\text { Standard } \\
\text { Error } \\
\text { (STERR) }\end{array}$ & $\begin{array}{l}\text { T Statistics } \\
(|\mathrm{O} / \mathrm{STERR}|)\end{array}$ & Information \\
\hline $\mathrm{H} 1$ & $\begin{array}{l}\text { (X1) CSR } \rightarrow(\mathrm{Z} 1) \text { Financial } \\
\text { Performance }\end{array}$ & 0.355298 & 0.359152 & 0.016712 & 0.016712 & 21.260421 & Significant \\
\hline $\mathrm{H} 2$ & $\begin{array}{l}\text { (X1) CSR } \rightarrow(\text { Z2) Dividend } \\
\text { Policy }\end{array}$ & 0.239201 & 0.237526 & 0.023774 & 0.023774 & 10.061396 & Significant \\
\hline $\mathrm{H} 3$ & CSR -> Company Value & 0.082322 & 0.083180 & 0.013838 & 0.013838 & 5.948812 & Significant \\
\hline $\mathrm{H} 4$ & $\begin{array}{l}\text { (X2) Capital Structure -> (Z1) } \\
\text { Financial Performance }\end{array}$ & 0.478405 & 0.468231 & 0.042213 & 0.042213 & 11.333010 & Significant \\
\hline $\mathrm{H} 5$ & $\begin{array}{l}\text { (X2) Capital Structure -> (Z2) } \\
\text { Dividend Policy }\end{array}$ & $\overline{-}-014638$ & $-\overline{-} 0.013759$ & 0.014461 & 0.014461 & 1.012229 & $\begin{array}{l}\text { Not } \\
\text { significant }\end{array}$ \\
\hline H6 & $\begin{array}{l}\text { (X2) Capital Structure -> (Y) } \\
\text { Company Value }\end{array}$ & 0.004663 & 0.005883 & 0.006994 & 0.006994 & 0.666806 & $\begin{array}{l}\text { Not } \\
\text { significant }\end{array}$ \\
\hline $\mathrm{H} 7$ & $\begin{array}{l}\text { (X3) Ownership Structure -> } \\
\text { (Z1) Financial Performance }\end{array}$ & 0.070299 & 0.068055 & 0.024028 & 0.024028 & 2.925715 & Significant \\
\hline H8 & $\begin{array}{l}\text { (X3) Ownership Structure -> } \\
\text { (Z2) Dividend Policy }\end{array}$ & 0.395129 & 0.394299 & 0.023779 & 0.023779 & 16.616457 & Significant \\
\hline H9 & $\begin{array}{l}\text { (X3) Ownership Structure -> } \\
\text { (Y) Company Value }\end{array}$ & 0.096985 & 0.097858 & 0.018394 & 0.018394 & 5.272544 & Significant \\
\hline H10 & $\begin{array}{l}\text { (Z1) Financial Performance -> } \\
\text { (Z2) Dividend Policy }\end{array}$ & 0.161554 & 0.161937 & 0.015654 & 0.015654 & 10.320044 & Significant \\
\hline H11 & $\begin{array}{l}\text { (Z1) Financial Performance -> } \\
\text { (Y) Company Value }\end{array}$ & 0.056654 & 0.057336 & 0.012768 & 0.012768 & 4.437356 & Significant \\
\hline H12 & $\begin{array}{l}\text { (Z2) Dividend Policy } \rightarrow(\mathrm{Y}) \\
\text { Company Value }\end{array}$ & 0.589969 & 0.583561 & 0.060047 & 0.060047 & 9.825106 & Significant \\
\hline
\end{tabular}

Source: data processed

\section{c. Discussion}

1. The relationship of influence (X1) CSR Disclosure on (Z1) Financial Performance has a significant effect that shows a unidirectional relationship, with the better management of CSR Disclosure disclosures it will improve Financial Performance. 
2. Relationship of influence (X1) Disclosure CSR on (Z2) Dividend policy has a significant effect that shows a unidirectional relationship, with the better management of disclosure of CSR Disclosure it will have a good impact on Dividend Policy.

3. Relationship of influence (X1) CSR Disclosure on (Y) value of the firm has a significant effect that shows a unidirectional relationship, with the better management of disclosure of CSR Disclosure it will improve the level of value of the firm

4. The relationship of influence (X2) Capital Structure towards (Z1) Financial Performance has a significant effect that shows a unidirectional relationship, with the better the Capital Structure it will improve Financial Performance.

5. The relationship of influence (X2) Capital Structure towards (Z2) Dividend policy has the insignificant effect which shows the opposite direction, with the better management of Capital Structure it will have less impact on Dividend Policy.

6. Relationship of influence (X2) Capital Structure towards (Y) value of the firm has no significant effect which shows the opposite direction, with the better management of Capital Structure, will exacerbate the level (Y) value of the firm.

7. The relationship of influence (X3) Ownership Structure towards (Z1) Financial Performance has a significant effect that shows a unidirectional relationship, with the better the Ownership Structure will provide improved Financial Performance.

8. Relationship of influence (X3) Ownership Structure towards (Z2) Dividend policy has a significant effect that shows a unidirectional relationship, with the better Ownership Structure will have a good impact on Dividend Policy.

9. Relationship of influence (X3) Ownership Structure towards (Y) value of the firm has a significant effect that shows a unidirectional relationship, with the better the Structure of Ownership will increase the value of the firm

10. Relationship of influence (Z1) Financial Performance towards (Z2) Dividend policy has a significant effect that shows a unidirectional relationship, with the better Financial Performance it will have a good impact on Dividend Policy.

11. Relationship of influence (Z1) Financial Performance towards (Y) value of the firm has a significant effect which shows that shows a unidirectional relationship, with the better Financial Performance it will increase the value of the firm

12. Relationship of influence (Z2) Dividend policy towards (Y) value of the firm has a significant effect that shows a unidirectional relationship, with the better Dividend Policy, it will increase the value of the firm

\section{d. Theoretical implications}

The aim of the company is to increase the net income generated from the company's operations by optimizing the value of the company for the welfare of shareholders. Stock prices as a representation of company values that are often used by investors as a basis for making investment decisions in the capital market.

Maximizing company value is influenced by management control through the company's ownership structure and is used to regulate the company's activities in paying dividends for company profits.

\section{e. Managerial Implications}

The implications of management policy are in accordance with the company's objectives to provide welfare to shareholders and management through dividend policies applied by 
management to management's operating profit. In giving a decision, management cannot act alone but must go through a joint decision with the shareholders for the survival of the company and increase the value of the company in the future. Management must consider the composition of the capital structure carried out in order to facilitate management in making decisions in dividend policy for investors. This dividend policy needs to get attention to attract investors in investing.

\section{Conclusion}

Based on the data analysis that has been done before, it can be concluded that almost all the research hypothesis tests are accepted and have a significant effect with a significant level of 5\% with t-table 1,960 except the Capital Structure of Dividend Policy (H5) and Capital Structure of Firm Value (H6) so the hypothesis was rejected in the study. This requires special enforcement for management in considering the composition of the capital structure formed by the company so that dividend policy can be applied according to the company's objectives.

Limitations

Research has not fully discussed the problems that exist because of time limitations and deeper analysis. Hope researchers can be used as input for the next researcher and contribute to science.

\section{References}

[1] Harmono, Manajemen Keuangan Berbasis Balanced Scorecard: Pendekatan Teori, Kasus, dan Riset Bisnis. Jakarta: Bumi Aksara, 2009.

[2] Hwihanus, Antecedents Value of the Firm. Surabaya: LPPM Universitas 17 Agustus 1945 Surabaya, 2018.

[3] I. M. Sudana, Manajemen Keuangan Perusahaan. Jakarta: Erlangga, 2011.

[4] I. Fadah, "Faktor Penentu Dividen dan Biaya Keagenan Serta Pengaruhnya pada Nilai Perusahaan," J. Keuang. dan Perbank., vol. 14, no. 3, pp. 391-406, 2010.

[5] Rudianto, Akuntansi Manajemen Informasi Untuk Pengambilan Keputusan Strategis. Jakarta: Erlangga, 2013.

[6] S. Husnan, Manajemen Keuangan, Edisi Kelima. Yogyakarta: UPPAMP YKPN, 2007.

[7] Fakhruddin and S. Hadianto, Perangkat dan Model Analisis Investasi di Pasar Modal. Jakarta: Elex Media Komputindo, 2001.

[8] K. Ayuningtias, Dwi, "Pengaruh Profitabilitas Terhadap Nilai Perusahaan: Kebijakan Dividen dan Kesempatan Investasi Sebagai Variabel Antara," J. Ilmu dan Ris. Akunt., vol. 1, no. 1, 2013.

[9] B. Campsey and E. Brigham, Introduction to financial Management. United States of America: the Dryden Press, 1995.

[10] L. B. Stearns and M. S. Mizruchi, "BOARD COMPOSITION AND CORPORATE FINANCING: THE IMPACT OF FINANCIAL INSTITUTION REPRESENTATION ON BORROWING.," Acad. Manag. J., vol. 36, no. 3, pp. 603-618, Jun. 1993.

[11] R. Kochhar, "Strategic Asset, Capital Structure and Firm Performance," J. Financ. Strateg. Decis., vol. 10, no. 3, pp. 24-36, 1997.

[12] M. C. Jensen and W. H. Meckling, "Theory of the firm: Managerial behavior, agency costs and ownership structure," J. financ. econ., vol. 3, no. 4, pp. 305-360, Oct. 1976. 